Сузана

Марјаниќ

\section{Астралната метла и левитациските перформанси на вештерското тело*}

„Во името на отецот и на свети Вид, на вештерките да им изгори пичката!“ (rkp. IEF 783:11)

\section{Тријада: глупост, сомневање и вистина}

Го започнувам овој есеистички прилог на сеништа, за жал, со фусноти, со посвета на Сите вештерки, Вештери и Животни - на Мачките, Верверичките, Пајаците, Глувците, Жабите, што биле набедени како вештерски куќни демони (спореди Hill, 1988: 38). ${ }^{1}$ Следува цинично-корективниот пример од Самобор за страдањето на две цопернички: „Едната од нив намерно се стрмоглавила во калта на некакваси бразда и се задушила во неа; другата пак ја обесиле на Стражник на 'Галѓенак' (Галженак)“ (Lang, 1914: 127).

Со тоа не ја намалувам улогата на Оние злииее кои им прават кривда (негација на правдата) на дру-

* Со дозвола на авторката и на издавачите, преведено според Suzana Marjanić, „Astralna metla i levitacijski perfromansi vjestičjega tela“, Treća: časopis Centra za ženske studije, Zagreb, broj 1, Vol. IV, 2002., 226-249. гите, зашто и денес многумина бараат заштита од црната магија и од уроци, а пред нивните зли очи (магиски или секојдневни) бегам во овие сенишни редови, зашто не сум упатена во можната (текстуална и сииварна) одбрана од нивните енергии. На пример, Ј. Бујановиќ за Прапутник запишал дека една (бела) вештерка ги сотрела уроците на злата (црна) вештерка:

„Го излечила друга вештерка со помош на своите молитви, а тој морал да скока преку мотики, секири, гребла, лопати, штици и други работи, во кои вештерката хукала, се молела над нив и се крстела“ (Bujanović 1896: 234).

Можеби верувањата во вештерки може да се гледаат како остатоци од митската стварност на црната богинка на Почетокот која фигурирала и како сиирашна, црна богинка на Крајот, како што била, на пример, богинката Durgâ-Недостапна/Кâlî-Црна, со безброј лица и имиња. ${ }^{2}$

Фолклорната претстава од периодот во кој настанал Canon Episcopi обликувала две имагинации за

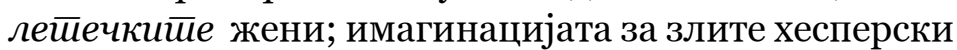
летачки кои биле слични на (римските) стириги и 
кои ждереле човечки органи, како и имагинацијата за добрите летачки кои носеле среќа како лейечки йалисмани, а летот го остварувале како придружба на богинката Дијана (спореди Bayer, 1982: 6465), а притоа, последните лешиови би биле блиски на современите екофеминистички сосйаноци во природа. ${ }^{3}$

На ирриказнайа за стварното постоење на вештерската религија (Craft) во концептот на култот на плодноста на Дијана, што го иницирала Маргарет А. Мари (Margaret A. Murray) можеме да ја додадеме йриказнайа на Роберт Грејвс (Roberta Gravesa) од Белайа богинка (1948) за тоа дека магискиот јазик кој бил поврзан со народните религиски свечености во чест на Богинката на Месечината или Музата бил потиснат во доцниот минојски период со доаѓањето на освојувачийе од средна Азија кои почнале да ги заменуваат матрилинеарните институции со патрилинеарни, па ги модификувале и ги фалсификувале митовите за да го озаконат новиой општествен поредок(Graves 1977: 9-10). ПонатамуГрејвсзапишува дека магискиот јазик иреживеал во мистериските култови, на пример, на Елеуса, Коринт, Самотрака и откако го потиснала христијанската сиррукйура на моќ, сѐ уште се подучувал на поетските колегиуми во Ирска и во Велс и во вештерските ковени на западна Европа (ibid. :12).

Можеме да започнеме и со приказната за сакралната абнормалносй, на пример дека историчарката на религијата Венди Донигер О’Флаерти (Wendy Doniger O'Flaherty) во книгата Аскейизмой и еройизмой во мийологијайа на Шива (Asceticism and Eroticism in the Mythology of Siva (1973)), го определува Шива како еротички аскет, како аскетски (девствен) бог кој истовремено е предочен итифалички, а притоа треба да се додаде дека митската слика на ерективниот фалус во индуската култура предочува и невиност. Авторката упатува дека митските фигури апсорбираат контрадикторни аспекти и притоа дејствуваат како медијатори, при што медијацијата е постигната со воведување на абнормалното, како што, на пример, и во случајот на Девицайа која раѓа исто така станува збор за противправилност и медијација (според Pandian 1991: 139). На митот за абнормалноста можеме да ја надоврземе приказната за вештерките кои од една страна (бели испостаси) или од Почейокой важат за такви коишто се предадени на бела магија (хербологија), а од другата (темна) страна или од Крајой дејствуваат како оние кои се иницирани во световите на црната магија. ${ }^{4}$ Се поставува прашањето кои од нив се вештерки? Очигледно белийе госӣод́, зашто, како што наведува Гвидион (Gwydion) - вештерките се борат против сотонистите од сите видови - магиски и политички. ${ }^{5}$

Приказната за вештерките може да започне со оддалечената приказна за современите вешиеерки - со случајот за африканската вештерка од Гана. Имено, осумдесетгодишната Џенет Тибу повела судска постапка за да ја спречи стогодишната практика која секоја година десетици жени ги прогласува за вештерки, осудувајќи ги на изолација и на сиромаштија. „Некои жени ги каменуваат до смрт, други ги префрлаат во логори во кои егзорцистите ги подлегнуваат на традиционални ритуали за истерувања на зли духови“. Се разбира, не е тешко да се погоди какви сѐ причини можат да предизвикаат некоја жена да биде прогласена за вештерка. Џенет Тибу е обвинета дека му фрлила магија на локалниот тревар кој тврдел дека сйарицайа е виновна за неговата сиромаштија и импотенција. Притоа, инйересен е случајот на обвинување за импотенција кој извира од архетипот на гинекофобија. ${ }^{6}$ 
Иван Ловриќ (1948: 160) упатува дека баорнициие им помагале на Морлаците против дејствувањето на вештерките; дека штитат од вештерки „само ако ги платиме“. Притоа, Ловриќ баорниците ги поврзува со йаганскай $а$, римска богинка Карна, која во неговата интерпретација „вештерките ги држела далеку од детските колепки“ (ibid. :160). Притоа Морлаците корективно-иросвет̄ииелски ги вбројува меѓу фана-

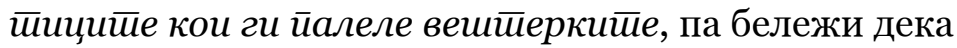
наведениот начин на унишйување на вештерки не го примиле од Римјаните „зашто кај нив немало фанатици, кои би ги спалувале“ (ibid.:162).

Или можеме да започнеме и со приказната за вагината на вештерката. Во Вагинални монолози, во поглавјето „Факти во врска со вагината“, цитиран е

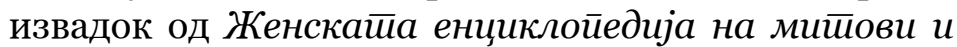
$\bar{u} а ј н и$, кадешто се наведува како на судењето на една вештерка во 1593 година, адвокатот на истрагата, инаку женет човек, очигледно за првпат го открил клиторисот; „го идентификувал како ѓаволска брадавица, сигурен доказ дека вештерката е виновна (...) Никој од посматрачите никогаш не видел такво нешто. Вештерката била осудена“" (Ensler, 2000: 47).

\section{Демойехника: тантрата и астралната метла}

Еден од текстовите кој остварува кибер-лет во интернетските замисли за метлите на вештерките е насловен Broomstick History (http://www. magickdragon.net/Bromm.html), што сугерира дека како што коњот им служел на вештерките за

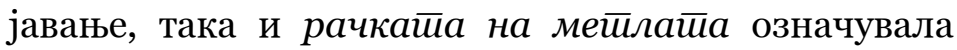
тантричко еротичко соединување, што би упатувало на симболизирање на фаличкото божество со метла. Јавањейо на метла може да означува еротичка, фемининаакииивнапозицијакојачестобилаосудувана како йерверзија, во која мажот се наоѓа во положба (не во улога) на коњ. Ричард Алперт (Richard Alpert) упатува дека во позицијата mathiuna (тантрички однос) жената седи врз мажот, при што станува збор за техника на еротизам на транспсихолошка проекција наменета за намалување на „ризикот на губење на свесноста (...) Оваа позиција на телото го успорува процесот на организмот овозможувајќи им така на партнерите задржување на свесноста преку динамиката на внатрешната свест“ (Alpert, 1994: 65).

Положбата на вештерката на метла еротички-сликовито ја опишуваат три глаголи - да се јава, да се

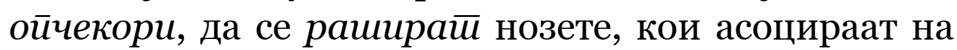
слика на полова практика. Мијат Стојановиќ (Stojanović, 1852: 384) бележи дека вештерките летаат „јавнувајќ́ ја метлата“. Или: во ливанското верување вештерките се опишани како жени кои нерадо излегуваат дење, „но затоа радо патуваат ноќе јавајќи на метла“ (Zubac-Ištuk, 1994: 154). Покрај тоа што (хрватските вештерки или можеби посоодветно вештерките во Хрватска) летале на метла, можеле, на пример, да летаат на вратило (дел од разбој) и на некои други астрални возила. ${ }^{7}$ Лука Олиќ Ориовчанин (Oriovčanin, 1846: 289) упатува дека вештерката лета на рашка (вител, мотовило, мосур за намотување, мавтало), вратило, метла; и „други предмети ноќе во воздух јава“. ${ }^{8}$ Следи пример од Банија: раскажувачот упатува дека уйроӣo на Ѓурѓ́овден (Јурјево), кога ги водел коњите на пасење, видел „како една женска, не кажувам која, јавна стап -тесен, висок дрвен сад во кој се мати путер; белешка на С. М.) со расилееиени коси и јаваше кон водата и се врати назад кон својата куќа“" (rkp. IEF 172: 136; курзив С. М.). Во Компољ

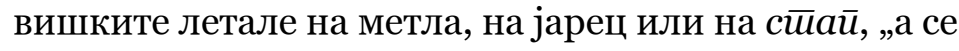
отиснувале во воздух со сйайалка (во Поле сйайаu- 
ца). За да гледаат каде одат, во рака држеле нагорче (зажарено парче јаглен)“ (Grčević 2000: 503).9

Мирча Елијаде (Eliade, 1985: 340) упатува на шамански екстази кои се изведувале на коњски стап. Во екстатичните танци бурјатските шамани користат стап со рачка во лик на коњска глава, при што и дрвениот коњ(че) (Hobby Horse) исто така е „во врска со екстатичкиот - но не нужно 'шамански' танц“ (ibid.

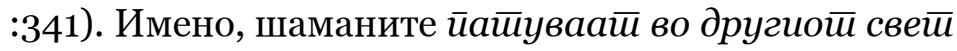
јавајќи на стап, со рачка во облик на коњска глава, тн. коњски сй $а \bar{u}$ „кој не е без сличност со рачката на метлите на нашите вештерки“ (Chevalier - Gheerbrant, 1987: 272). Екстатичното патување се припишува на концептот на йалкачка душа (Motz, 1996: 81), при што се верува дека неколку души престојуваат во човечкото тело и дека талкачката душа може да го напушти телото во сон или во ексйаза (ibid.). Во шаманските сеанси со имитирање звуци и движења на животни, шаманот ги повикува анималните помошнички и со тоа влегува во менталниот облик на животно, зашто во йранс шаманот трага по животинските способности. Елијаде (1985: 132-133), кога ја интерпретира орнитоморфната шаманска облека, упатува на Охамарксовото толкување според кое орнитоморфниот симболизам се поставува во врска со верувањата во духови ӣомошници на кои шаманите им овозможуваат астрална проекција во уранската топографија. Притоа, Мирча Елијаде упатува дека воздушниой симболизам е универзален и поврзан со шаманите, врачовите и митските суштества.

Во астралното патување кое го овозможуваат соништата, духот или „егото“ го напушта телото и за егзистенцијата на Земјата останува врзан само со Сребрена врвка (Lobsang Rampa, 2000: 179). „Но рачките од метли, колку и да служат за 'рационализација' на она во што луѓето не сакаай да веруваат, не се неопходни“ (ibid.).

На Гоината сликовна имагинација на вештерскиот лет (Извонредна учийелка!, 1799) се наоѓаат две голи и развеано-долгокоси вештерки на една метла, при што иириаголникой на метлата е сврииен кон найред; старата вештерка се наоѓa во улога на водителка на астралната навигација. ${ }^{10}$ На пример, Глобусовиой фотографски прилог - кој го следи текстот за тоа како 309 години после ловот на вештерки во Салем, потомците на жените кои биле обесени во 1692 година барале тие да се прогласат за невини - прикажува вештерка (манекенка) во лет на метла, при што триаголникот на метлата традиционално иконографски е сместен зад (вештеркиниот) задник. Имено, американската влада во 1957 година „ја испрала стигмата од некои имиња, а сега потомците на пет жени - Бриџит Бишоп, Елис Паркер, Маргарет Скот, Вилмот Ред и Сузан Мартин - бараат и тие да бидат вклучени во списокот на невините“. ${ }^{11}$ Во книгата на Маријан Кошичек Мийой и сексой (1991), во поглавјето „Жртвување на жената“ се наоѓа сликовниот прилог „Вештерки“ на Ханс Балдунг Грин (Hans Baldung Grien), на кој, покрај останатите вештерски сценографии, се прикажани три млади и голи вештерки и една постара и гола (во заднината) која лета на чаталест стап, а во прегратките држи една од младите голи девојкивештерки. Наведената чаталеста гранка/стап на кој лета остарената вештерка иконографски е блиска на магионичарскиот закривен стап со рогови (спореди Hill, 1998: 10) и на чаталест вид вретено.

На пример, во Каставшина е забележена дренова метла (спореди Jardas, 1957: 104) којашто вештерката 
Званка ја извлекла од под постела; потоа јајавнала и ја изговорила психонавигациската формула - „Летај, метла, кај Бенкошќин!“ - при што „фиукнала за миг надвор на метлата“.12 Во Пригорје се верува дека цеиерњициие јаваат и на Клек на метла [јашиду и на Клек на мекли“ (Rožić, 1908: 98) ]. Во Имотска краина е забележен лет на равули (драчевили, за драч со два крака), на косор (косир, срп без надворешно закривување), на мейла и на жарач: „Се слекоа, се намачкаа, секој го јавна својот коњ и сите заедно рекоа: 'Ни по дрво ни по камен, туку кај Дубоковиќ во коноба по вино!'“ (Kutleša, 1993: 384). Во Сињска краина е забележено дека откако вештерките се намачкале со маст, една скокнала на столче, а другата „на некое друго нешто, и со ѓалот, вјавнале на гранките“ (спореди Bošković-Stulli, 1967/68: 406). Во Подравина е забележен лет на вештерки на планината Харшањ на „можџара“ (бутин, аван, мортар; сад со толчник во кој се йолчи шекер, бибер и кафе) откако би се намачкале со маст (Franković, 1990: 68). Во Билогора е запишано предание според кое „некоја баба“ јавала на вретено; во раката имала маша, „а косите расплетени и црвени како пламен“, при што очевидецот во лейечкайаженаја препознал сосетката (Lovrenčević, 1969-1970: 88). И додека вилинските жени се замислувани во животот на природата, одвоени од човековиой праг, вештерките фигурирале во соседските препознавања, зашто за разлика од категоријата Добро, Злото секогаш е конкретизирано. Злото е секогаш присутно сега и овде.

Со симболот на вретеното (кое со остриот врв упатува на итифалички симболизам) $)^{13}$ е поврзана германската Берхта на која ѝ се припишани дванаесет „празни вретена“, како што наведува Н. Нодило (N. Nodilo) според записите на Јакоб Грим (Jacob Grimm) од Deutsche Mythologie, при што симболизмот на вретеното се поврзува и со сидералниот симболизам. Упатува како Скандинавците вретеното и фурката на Одиновата сопруга ги препознавале на небото во констелацијата на Орион, чиј sвезден појас го именувале Friggjarockr (Friggae colus), што е блиско до јужнословенските именувања за Орион - Бабини

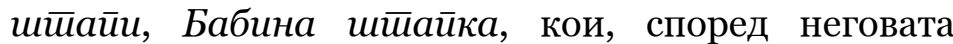
интерпретација, упатуваат на митската меморија дека преѓата од појасот на Орион потекнувала од вретеното на старословенската богинка на плодноста (Nodilo, 1981: 263). Како и вретеното, и фурката се вбројува во итифаличкиот симболизам и во симболизмот на иницијација во полова љубов. Вретеното асоцира на законите на вечното враќање (цикличко космичко струење) и на лунарниот симболизам (спореди Chevalier - Gheerbrant 1987: 767). Фурката и вретеното/предењето фигурираат како атрибут на богинката на предачките, ткајачките и наречниците. Сите богови на судбината, на усудот, иконографски се забележени како предачки и ткајачки и се осликуваат во тројното лунарно обличје на триморфното Време кое ја обликува анатомската судбина на Богинката (спореди Cooper, 1986: 188; Durand, 1991: 276).

Приказната за метлата како вештерско астрално возило можеме да ја продолжиме со приказната за метлата во илустрираната книга Вешиеерки и волшебници на Даглас Хил (Douglasa Hilla). Станува збор за стилизирана метла (вештеркин ат) за која авторот забележува дека ѝ припаѓала на „една вештерка од Девон“ и притоа го запишува верувањето според кое вештерките како небесни лейачки летале на мотики, лопати и метли. Претставата за вештерската навигација на споменатите возила веројатно извира од архаичните обреди во кои танчерите користе- 
ле алатки со подолги рачки како дрвени коњи (Hill, 1998: 10). ${ }^{14}$ И додека на вилите им се придодадени крилја и закрила како орнитоморфни помагала во психонавигацијата, ${ }^{15}$ вертикализмот и ангелизацијата на еротизмот, на вештерките им е придадено астрално возило во натуралистичка симболизација на фалусоидна рачка ( $a \bar{u})$. Рачката на „метлата од Девон“ е обоена со жолти (Сонце), сини (Небо) и зелени (Вегетација) ленти, а йриаголникой на метлата (интересно е што Д. Хил не наведува од кои растенија/стебла е изработена метлата) е обвиен со три реда врвки - бела врвка меѓу црвени. (Упатувам на визуелизација на астралната метла, но за жал не и на практиката, освен секојдневната - со метла, правосмукалка или неодамна рекламираниот Sweep). Наведената симболизација на боите, која е битна во хромотерапијата, ме потсетува на зборовите (баење) кои ги користи (ги користела) бабайа бајачка за лечење на очите. Таа исцелителска практика (од Горски Котар) вклучува три гранчиња метла со кои исцелителката ги прекрстува очите и притоа го изговара вербалниот симбол на обредот:

„Три Марии редум гредат, три Марии - три сестрички. Една носи бела метла, една црвена метла, една носи црна метла. Која носи црна метла, ја тера злобницата: злобо-злобницо! Те колнам со живиот бог, правиот Бог, вистинскиот Бог - бегај надвор од на стариот Антун окото“ (Duić, 1896: 286).

Станува збор за иконографија која ја привикува митската меморија на Троичната Богинка/Тројното феминино суштество - Девојка, Мајка и Старица/Сйара вештерка (спореди Rountree, 1999: 82), при што последната Марија (Атропа) е означена со „анимозитетната“ (во наведениот случај на баење станува збор за исцелителската боја) со црна метла („со ножици“) со која се пресекува нишката на боле- ста. Трите космички бои - белата, црвената и црната - упатуваат на бојата на небото, на средишниот свет и на топографијата на подземјето; бојата на Девицата (пред појавата на првата месечна крв), црвената Мајка и црната Крона, од кои последната во низата е андроцентрички именувана со сйара (црна) вештерка. ${ }^{16}$

Пенеторн Хјуз (Pennethorne Hughes, 1975: 50) кажува дека ацтечката богинка Тлацолтеотл (Богинка на калй $а$, богинка на Земјата и на йоловайа љубов) се прикажува со конусна шапка и како јава во воздух на рачка од метла. Притоа, интересна е и кинеската богинка Сао Ч’инг Нианг како богинка на поволното време која го чисиии (го мете) времето за да биде јасно. За време на големите дождови, девојчињата ја прават нејзината фигура од хартија и ја закачуваат во близина на кал, а во сушен период го извршуваат истиот обред за богинката да испрати дожд. ${ }^{17} \mathrm{Ha}$ пример, меѓумурската поговорка „Времето се мете“ се користи токму за надоаѓачко невреме (Bajuk Pecotić, 1999: 134).

Современата вештерка Гвидион (Gwydion 1994: 58) бележи дека метлата традиционално се изработува од три вида дрво: рачката е направена од јасен (Дух/ воздух) низ кој вештерките „мораат симболично да патуваат“. Триаголникой на метлата се изработува од брезови гранчиња, а посветен ѝ е на Белата Госпоѓа,

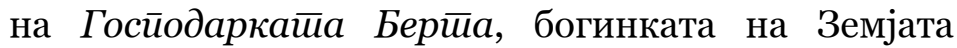
преку која сите вештерки настојуваат да постигнат прочистување и иницијација, а притоа гранчињата на брезата се врзуваат со врбини гранки кои ја симболизираат Месечината и со магла обвиените води кои мора да се поминат ако се сака да се влезе во кралството на смртта и мудроста. Исто така, Гвидион спомнува дека верувањето според кое вештерките 
летаат на метли е „очигледно неразбирање на магиско-поетската шифра која укажува на шаманистичка трансна екстаза и визионерски лет на духот“ (ibid.). ${ }^{18}$ Како и на вештерката, на која метлата ѝ е асиррално и йсихичко возило, и мориниот атрибут е метлата која кај индоевропските народи се нарекувала - во фантастичната определба кај Нодило (Nodilo, 1981 :61) - воинсиивен симбол на зимайа, „страшно оружје на зимската грдосија. ${ }^{19}$ Притоа ветерската мора Нодило ја интерпретира како зимски демон, па со обрнување (вртење наопаку) на нејзиниот симбол, се оневозможува нејзиното зимско дејствување. Нодило понатаму упатува како на Индоевропејците зимата им се чини како „сениште (...), како некое жениште препакосно и сотрувачко“ (ibid. :142-143) и дека во Грбаљ котарски вештерката ја именуваат со вейерско вейришйе (ibid. :60). „Денес, нејзината (морината; заб. С. М.) метла е помалку опасна, нема удар. Јаваат на нејзе кукавички вештерки“ (ibid.), со што Нодило го намалува вештерскиот демонизам во однос на демонизмой на морините акции. Метлата е симболички поврзана со аспектот на летот и ветрот, а месопотамското (вавилонско-асирско) име за архидемонот Лилит го означува духой на веиеерой со кој е поврзана една страна на морината демонска идентификација. Во хрватските народни верувања метлата често се определува како апотропеј против морите и вештерките, при што значајно упатство е дека метлата треба да се йреврӣи наойаку зад вратата (Stojković, 1935: 28). Франо Иванишевиќ (Frano Ivanišević, 1905 :233) бележи верувања од Пољице според кои ако за некоја жена која дошла во куќата постои сомневање дека е вештерка (višćica), потребно е да се сврти „комоштрата [котел што виси над оганот, заб. прев.] наопаку, и метлата зад врата да се стави наопаку, не знае ли да излезе вонка, таа е“. Или уште еден пример (покрај бројните други примери):
„Ако метлата на влезната врата на куќата или на шталата ја свртиш нагоре, вештерката ја губи моќта“ (Tršće, 1998: 127). Метлата која остварува функција на чистење, истерување и уништување на старото (значи, и на нечистото) со нови (чисти) сили, е симбол на револуционерен корекйив. Зашто, како што со метлата се мете нечистотијата и ѓббрето (при што станува збор за материјално чистење), во метафоричко значење метлата проектира и духовно чистење, со кое се „мете или се изметува злото, се нападува духот, несреќата, урокот, болеста, смртта; тоа е обредно и магично чистење“ (Stojković, 1938: 25). Со својата структура метлата го обединува машкиот принцип - фаличкиот симбол на рачката на која јава - лета

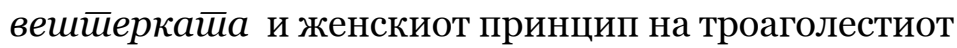
(делтаст) врв, и со тоа симболички ја предочува противставеноста помеѓу чисӣойо (фаличката рачка во рацете) и нечисӣойо, ойаснойо (женскиот триаголник на метлата која мете) (спореди Radenković, 1996: 150-151). Со примената на астралната проекција, метлата се преобликувала „од инструмент на угнетување во инструмент на ослободување“ (Petek-Stupar, 1999: 80). Викторија Фауст (Viktoria Faust, 2000: 45) упатува дека во свадбената церемонија (ритуалот на врзување), понекогаш се практикува архаичниот ритуал на плодноста - јавање на мейли.

И додека астралната метла, која е значаен иконографски инструментариум на вештерската демотехника, се исчитува или во симболизмот

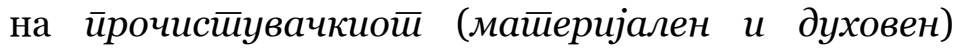
корекииив, или во Нодиловото определување

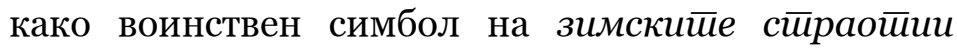

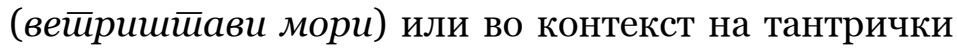
однос, вратило, рашак, вретено - кои се поврани со техниките на ткаење и предење - ги поврзуваат вештерките со богинките на судбината (ткаењето); 
равуљите (вилите задрач), косорот - како земјоделска алатка - ги поставуваат вештерките во контекст на култот на вегетациските циклуси; бутимот (аванот), стапот - како садови за подготвување на храната - ѝ придаваат улога на хранийелка; машата ја врзува улогата на вештерката за култот на огништето како сакрално место во куќата каде што вештерката/ старицата како чуварка на светиот оган/огниште практикувала паганска (селска) религија/магија, зашто традиционалното вештерство се однесува на култот на вегетацијата и на плодноста на стоката. Мирча Елијаде (Eliade, 1983: 214) упатува на гинекоморфната симболика на огништето (огнишйе=вулва) како седиште на оганот.

Така може да се постави и теоремата за левитацијата која им припаѓа на сидхи-моќите (Hozzel, 1991: 12). Познати се искуствата на левитација на христијанските мистици, светци, на пример искуството на лейечкиой свейец Доминик (ibid. : 17). Проспер Ламбертини, подоцна папата Бенедикт $\mathrm{XIV}$, забележал седумдесет случаи на левитација во близина на Копертин, родното место на најславниот од сите „летачи“ Јосип Копертински (ibid.: 16). Еден запис кој припаѓа на хрватскиот фолклорен имагинариум за вештерските левитации, астралната домотехника ја споредува со лет на пердувче (rkp. IEF 1127: 18).

Впрочем, зошто не би поверувале во можносйа на вештерските летови, зашто, на пример, староиндиските текстови, како што наведува Ерих фон Деникен (Erich von Däniken, 2000: 129), известуваат за летечки возила. Во Ригведа се опишани и видовите погонско гориво за астрална навигација; меѓутоа, незгодно е што одделни зборови за мешавините на течностите денес веќе не можат да се преведат. „Една анализа на ‘имагинацијата на движењето’ би покажала колку копнежот за летање е битна состојка на човечката психа“ (Eliade, 1985: 348).

\section{... и вештерска маст за левитација}

Томислав Хрушковец (Hruškovec, 1998: 31) бележи дека главните состојки на вештерските масти биле растенија што содржат атропин и скополамин кои во помазаникот „предизвикуваат привиденија и бунило (...), а тоа се гледа и од древните упатства, како и од мастите кои содржеле мандрагора“ која содржи „атропин, скополамин и хиосциамин, кои во поголеми количества предизвикуваат бунило, халуцинирање и епилепсија, додека, од друга страна, внимателно дозирани, ги лечат истите тие болести и предизвикуваат сон“ (ibid. : 25). ${ }^{20}$ Се разбира, жените биле обвинувани заради поседување на „гаволската маст“, како што била обвинета Магдалена Калопањка во 1734 година во Турополе зашто наводно летала со вештерките на Медведница, кои ја мачкале со „ѓаволска маст“ (спореди Laszowski, 1914: 207). Формулата (вербалниот симбол на обредот) која се изговара откако вештерката ќе се намачка со маст е завршниот магиски акт кој ја остварува нејзината навигација: „Ни по дрво ни по камен, туку во Пуља под орев“, при што Маја Бошковиќ-Стули (Bošković-Stulli, 1991: 135) бележи дека топонимот Пуља ја означува Пуља (Pugliu) во јужна Италија. ${ }^{21}$ Петар Кадчиќ Пека (Kadčić Peka, 1859: 332) објаснува дека вештерките заминуваат во Пуља затоа што „во Пуља (има) многу ореви и тоа големи“. На Брач наведената формула гласи: „Ни по дрво ни по камен/ Тук' во йоле под орев“ (Carić, 1897: 711; курзив С. М.). ${ }^{22}$

Иван Ловриќ како вештерски престојувалишта ги определува црните облаци и ореовите стебла, при 
што Морлаците забележале дека оние кои спиеле под ореови стебла „бедно погинале. (...) Философите причината ја наоѓаат во испарувањето на оревот, но Морлаците не се философи“ (Lovrić, 1948: 160). ${ }^{23}$ Интересно е што вештерките се поврзани со ореовото стебло - кое инаку фигурира како стебло поврзано со подземната топографија (спореди Čajkanović, 1985: 185) - со оглед дека е йолово определено како машко стебло, за разлика од, на пример, буката, праската и границайа (вид храст) кои биле сметани за женски стебла (спореди Nodilo, 1981: 535). Да се присетиме и на Каријатидите кои фигурираат како ореови нимфи (спореди Graves, 1969: 239). Така, постојат и записи според кои вештерките своите жришви ги издигале (ascensus) на стебла; на пример, Катарина, ќерката на Агата Новосел од Шчитарјево, која им се намерила на „цоперниците, а мож' и на дусите нечисти, била однесена на врво на највисоко дрво и отаде сакаајќи пеколните маки наглава да ги зафучи, почнала побожно да привикува името на Марија бистричка“ (Boranić, 1912: 371). ${ }^{24}$ Како собирни центри на моќите на вештерките се означени планините (врвовите), во определбата на Елијаде на Космичкайа йланина, и стеблата (arbor mundi), при што станува збор за Земјините центри-испакнатини (axis mundi) кои ја воспоставуваат врската помеѓу епиуранијата и епигејата (спореди Eliade, 1985: 205). ${ }^{25}$

Иван Милчетиќ (Milčetić, 1896: 233) забележал за

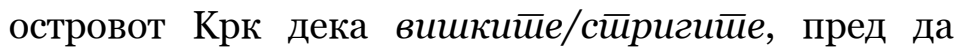
одлетаат, ќе се намачкаат со маст која ја чуваат во лонец йод огништето. Во Буковица е забележено предание според кое стиарайа вештерка се соблекла гола; земала мотка па удрила со неа „по капак кај огнот и заваби како да мами овен пред себе. Кога излезе едно мало лонче колку орев, старата со него се намачка цела од петици до глава и рече 'Ни по дрво ни по камен, туку под орасот под Примина““ (Ardalić, 1917: 306). Во вешиеерскаӣа религија голотијата функционира како ритуална практика со која се остварува струење на внатрешниот глас. Со соблекувањето на облеката ја расекуваме луковицата нанашайа маска:„Мистичнотозначењенаголототело е 'вистина"“ (Starhawk, 2000: 51). ${ }^{26}$ Волшебничкише, вештерките кога гатаат, маѓепсуваат, расӣашани ce (Stojković, 1934: 14), со расплетени коси и боси, зашто врвките и обувките ја задржуваат волшебната моќ, протокот на енергија. Вештерките обликувале женска распашана контракултура каде ослободеното Женско не се наоѓа под надзор (и казна) на цврстиот, машки корективно-педагошки ӣojac. Меѓутоа, во теолошкиот имагинариум за вештеркскиот сабат, се разбира, им е придаден голем и заслужен маж (Ѓавол) кому му служат како асистентки. Како и морите, и вештерката дејствува во раскинатата биографија која ја сочинуваат дневната Пасија на Домаќинка и никтоморфната расӣашана Акција која во теолошките Вистини е демонизирана.

П. Кадчиќ Пека (Kadčić Peka, 1859: 332) за Макарска наведува дека вештерките имале „лонче помаз од специјални растенија, обично закопано под каминот или огништето, забајан кибрит“. Кога мораат да патуваат, „ќе чкрапнат“ со шкорчето по земјата што ќе се разотвори, ќе се намачкаат со помазот: „и ќе чкрапнат повторно по земја, земјата ќе се затвори без да се познава. Кога може, се изговорува: 'Ни по дрво, ни по камен туку во Пуља под Ореви'“. Исто така, Стјепан Бановиќ (Banović, 1918: 190-191) бележи како секое вештичиште има „свое лонче маст, што ја мачка и изговара: 'Ни по дрво, ни по камен, туку во Пуља под орас!'“, при што упатува дека лончето сииои во огништето: кога им треба, со стапче удрат по камино, „а лончето ондак само излегуе ванка“. На Брач се 


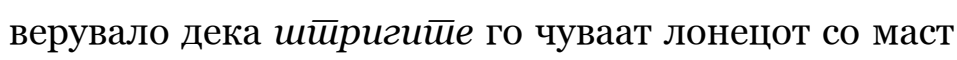
„во еден жив камен“ (Carić, 1897: 710). Лука Илиќ Ориовчанин (Oriovčanin, 1846: 291) го бележи верувањето според кое вештерките се мачкале под мишка и по табаните со „вилинска маст“ пред да одлетаат низ прозор, а која една вештерка според упатствата од една приказна ја чувала под греда. Наведената вештерка пред остварената навигација на своето место во постелата ставила метла.

Како подготовка за вештерското возење, вештерките користат опојни масти и напитоци (мокуница, мандрагора, беладона и мескалин), при што Егон фон Петерсдорф (Egon von Petersdorff, 2001: 154) од своите идеологеми верува дека со тоа се воспоставува врска со демоните „со посредство на изрично или премолчано спогодување со ѓаволот“.27 Притоа се поставува прашањето дали вештерското возење се случува во телото или само во имагинарните визии „кои претходно во фантазијата ги предизвикал некој демон“ (ibid. :155). Етнологот В. Е. Појкерт (W. E. Peuckert) според еден средновековен рецепт направил вешиеерска маст од кужњак (Datura stramonium), беладона, мандрагора и уште неколку билкички кои ги втривал под мишка и на челото. Дваесетичетиричасовната состојба на опиеност и длабок сон ги опишал со сликите на „диво пеколно јавање, љубовна опиеност, фантастично летање во бесконечност, тврдина среде изобличени наказни суштества“ (сӣоред Petersdorff, 2001: 162). На пример, буниката (мандрагората) во јужнословенските народни песни се спомнува како опојно средство, а притоа Павле Софриќ (Sofrić, 1912: 59-6о) наведува дека старите Словени верувале оти буниката ги изгонува ѓаволите и дека нејзините семки можат човек „невидлив да го сторат“.
А покрај тоа што вештерките ги мачкале со маст своите тела, со неа исто така ги мачкале и своите летала - „метлите, фурките, стаповите и клупичките“ (Hruškovec, 1998: 31-32). Во Комполе за вештерската маст се верувало дека станува збор за масло кое се добивало од украдено млеко, а особено било добро маслото кое вештерките „го топеле од млекото украдено од жените кои дојат“ (Grčević, 2000: 503).

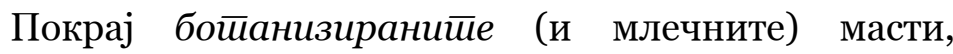
забележени се и верувања во закрвавени масти, при што во Самобор е запишано дека цопрницата мора да „се спари со ѓаволот, да роди дете, тоа дете мора да умре и толку долго да се вари, додека да стане маст“ (Lang, 1914: 123). Исто така, во Самобор постоело верување дека вештерската маст може да оствари психонавигациска невидливост; „која ги праи невидливи и да мо’ат да летат“ (ibid. :125). ${ }^{28}$ Маста ја прават од невиденчиња (деца „шо умираа пред крштевање“), при што ќе се намачкаат со маст под мишка (наведената употреба потсетува на деосиик), а „меклата ја оставава дома место себе“ (ibid.). ${ }^{29}$ Ф. Иванишевиќ (F. Ivanišević, 1905: 238) бележи дека вештерската маст смрди „’ко пекол“.

Со наведените имагинарии вештерската маст главно е поврзана со култот на огништето (lararium) кое е седиште на родовски куќни идоли, на душите на претците (Vukanović 1971: 174). На прекладата (држач за потпирање на кладите) како на родовски идол на подрачјето на Јужните Словени и е принесувана човечка крв на која се правеле магии или се гатало според тоа дали крвта зоврела или не. Провриената крв се исчитува како несреќен знак за родот; тогаш ја напуштале куќата и прекладата-идол (ibid. :188-189). Поврзувањето на вештерската маст во фолклорните замисли со топосот на огништето може да се означи 
како остаток на паганската религија која особено ја практикувале постарите (во значење: йовешӣu, поискусни) жени (старици, баби вешӣерки).

Халуциногените афродизијаци кои ѝ припаѓаат на категоријата на еротичкото чудесно во облик на маст предизвикуваат летаргија и каталепсија, зашто сабайой со своите игри се одвива мирно во кревет, во сон, под влијание на наркотици (спореди Castellan, 1986: 12), што значи дека во случајот на летот во имагинарните предели на слободата, станува збор за подрачјето на метапсихологијата. Во споредба со трансот кој се темели на движење, врева, друштво, криза, сетилна престимулација, амнезија, без халуцинации; во екстаза - станува збор за неподвижност, тишина, самотија, отсуство на криза, отсуство на сетилна престимулација, сеќавање, халуцинации (спореди Antonijević, 1990: 9), ${ }^{30}$ при што вештерската психонавигација имала обележје на екстаза, додека никтоморфните собири (ритуалните села) би се впишувале во структурата на трансот.

Мене особено интересен приказ на обредот на мачкање маст ми се чини записот од Имотска краина: главната вештерка Ружа донела јаже, лонче и четири цевки. Притоа, на секоја вештерка и дала по една цевка;

„лонецот на среде, јажето го врза на ореова гранка двојно. Ружа прва гола се слече, брцна рака в лонец и се намачка по чело, по плешките и по половината. Фана јажето и се преметна ваму-таму, постлем со цевката удри по лонецот, говорејќи: 'Мое лонче котарче, ни од дрво ни по камен туку во Пуља под орас!' И се престори Ружа во гуска“ (Kutleša, 1993: 383).

Се разбира, продолжението следи, но заради фрагментарноста, мозаичноста на есеисииччиой ирилог на сенки, давам само дел од записот за вешииеркийегуски, со оглед на тоа дека мийскийе вештерки сейак и йокрај сѐ спаѓаат во мизогини фантазми.

\section{Зоопсихонавигацијата и астралното јавање/лет на животно и маж}

Вештерската (како и морината) никтоморфна акција е означена со инотворење на душата, со раздвојување на душата од телото, при што душата влегува во процес на зоометемпсихоза. Вешиеерскиие техники на излегување од телото (спореди, на пример, Carić, 1897: 710; Milčetić, 1896: 233; Bošković-Stulli, 1959: 223) упатуваат на доктрина на метемпсихоза која почива на замислување на телото како обвивка на душата. При астралната психонавигација телото (на жената - мора, вештерка) останува в кревет, а душата влегува во процес на териоморфна метемпсихоза. Станува збор за никтоморфната зооматеријализација на алйер егойо. Душата партиципира и во анималниот живот (anima/animalis); вештерката (како и мората) фигурира како психонавигатор на женииее-живойни, живоииинскойо во женското (животинското како инотворена душа). Зоопсихонавигацијата се остварува како зоометемпсихоза зашто метемпсихозата бара трансгресија преку смртта (привремена смрт). ${ }^{31}$ При хесперската психонавигација се верува дека можат да поминат низ секоја дупка во куќата, а како доминантно верување е определена можноста на нивното поминување низ клучалка. Владимир Ардалиќ (Vladimir Ardalić) за Буковица го забележал верувањето дека вештерките можат да влезат низ клучалка и дека најмногу се претвораат „во летечки работи, како секакви птици, црни квачки и во гуски“ $(1917: 306) .^{32}$ Мијат Стојановиќ (Stojanović, 1852: 384) бележи дека од заспаното вештеркино тело излегува духой, а те-

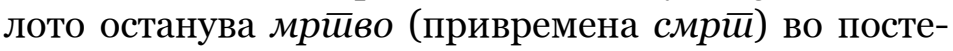




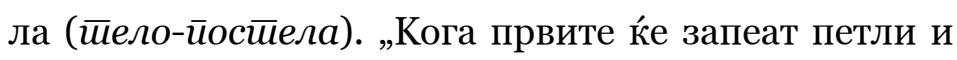
така ќе почнат зората да ја поздравуваат, ете духот се враќа, и пак влегува во телото“. Ако телото на таквата жена (вешйерка) се сврти наойаку во креветот, нејзиниот дух/душа не може да го оствари враќањето

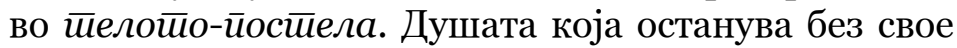
тело-престојувалиште-обвивка станува опасна:

„(...) кога бабата вештерка осамнала мртва, секоја ноќ доаѓала душата и како сениште се мачела низ куќи, лонците и другите глинени садови по кујната ги трескала, ложела оган, расфрлала, ги плашела луѓето и на крај ја запалила куќата“"(ibid.).

Покрај (зоо)метемпсихозата, вештерките со морите споделувале и определени никтоморфни активности. ${ }^{33}$ Мијат Стојановиќ (Stojanović, 1852: 384) бележи дека вештерките можат да се претворат „сега во мачки, па во квачки, па во вошки, па во лилјаци, па во утови“, и предупредува дека покрај другите штетни дејствувања, „навалуваат на мали дечиња цицалчиња“. За Прапутник, Бујановиќ (1896: 234) забележал дека вештерките „се престоруваат“ во (инкубни) мачки: „Вештерките доаѓаат ноќе како мачки на човекот и го цицаат, па другиот ден му се дујат градите“.

Првобитните териоморфни божества, кои се обликувани во тотемизмот, ӣодоцна добиваат човечки облик (антропоморфизација на териморфизмот), но не ја губай врскайа со животното - стануваат

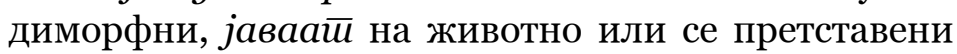
заедно со него (на пример, Атена/Минерва со утот), и на последниот степен на преобразба животното станува „само атрибут или симбол на божеството во човечки облик“; на пример, божеството-елен најјасно се очитува во Кернуносу (Zečević, 1964: 705). 3оометемпсихозата како премин во анатомската суд- бина на животинството и замислата за вештичиниот никтоморфен лет на животни може да се впише во архетипот на анималниот динамиам; на пример, Маите „отсекогаш користеле животински симболи за да ја изразат силата, итрината, лукавоста и моќта на несфатените богови“, а истото го прават и Индијците (Däniken, 2000: 134).

Иван Ловриќ (Lovrić, 1948: 159) во контекст на верувањето на Морлаците, ги толкува вешерките како „оние кои ноќе крештат и летаат вадејќи им ги срцата на децата во колепки“; нивниот глас потсетува на ноктоморфното хукање на утот. ${ }^{34}$ Притоа додава дека станува збор за римско наследство, додека верувањето на Морлаците дека вештерките се претвораат во пеперуги, „кои затоа и се нарекуваат вешиширки“, не го пронаоѓ⿱㇒⿲丶丶㇒ во римскиот систем на верување. Можноста да се претворат во пеперуги се одредува со метемпсихоза, а на архетипската вештерка ѝ се придава патријархалната фантазма за Крона - сииари немажени жени кои се луйай „што не се омажиле, па се даваат на тој занает“. Интересно е што притоа вештерката ја споредува со грчките Сибили, при што

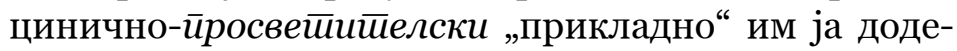
лува синтагмата „будалести грчки Сибили“. И притоа бележи: „Почитувањето од старите на грчките Сибили, кај Морлаците преминало на вештерките“ (ibid. :160).

Милан Будимир (Budimir, 1966: 272) упатува на претстави одминојската епоха за „душата наумрениот предок во облик на пеперуга (Seelenschmetterling)“. Забележено е дека со зборовите вештерка и врколак се именува и пеперугата која ноќе лета околу светилката, а се нарекува уште и мртовечка глава (Acherontia atropos). „Сродната пеперуга со помал формат се нарекува вешӣерка“ (ibid.). „Вишката - 
ноќна пеперуга - околу ламбата изгорува на огнот. Ако утре дојде некој нешто да побара (женско), не смее да се даде, зашто тоа вишката дошла себе да се откупи“(rkp.IEF 285:45). ${ }^{35}$ Ноќнатапеперуга Психин облик. Милан Ланг (Lang, 1914: 121) во Самобор го забележал верувањето според кое цопрницата знае „да се претвори во крастава жаба (голема)“ и притоа упатува на народскиот коректив дека таквата жаба мора „на железен рог да се набие, ил’ со камењ да се убие, да биде една цопрница помалу“. ${ }^{36}$

Покрај верувањето во вештерската зоометемпсихоза, постојат верувања и во зоометеморфоза: на пример, во Имотска краина е забележено претворањето на една вештерка во блејавица/овца и на две вештерки во крилайици/диви гуски, откако се намачкале со маст. „Од лончето со маст ќе се намачкаат и низ јаже

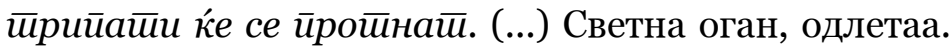
Овците гуска носат“"(Kutleša 1993: 385; курзив С. М.). ${ }^{37}$ Матија Ваљавец (Valjavec, 1863: 254) за Вараждин и за неговата околиназабележалфантастична вештерска/ анимална телесна дислокација: цопрницата имала „козја глава место својата, а својата ја држи в рака, па ѝ пошти вошки“.

Во рамките на ноќните активности, вештерките остваруваат динамизам на промена на анатомската судбина, а во рамките на динамизмот на душата („летна к’о стрела; Ivanišević, 1905: 238) е обликувана вештерската митска орнитологија („полетаа преку морето дур' во Брач; ibid.). Вештерското тело е протејскоипротетскотелокоетрагапонадоместување на орнитоморфното воздигање на духот, на душата и по безграничната моќ на фантазијата. Мирча Елијаде (Eliade, 1985: 349) упатува дека симболизмот и митологијата на магискиой лет, симболиката на летањето и митологијата на душата-птица

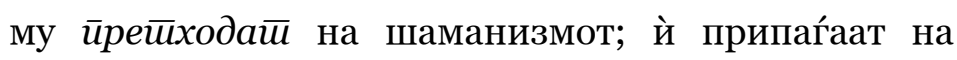
идеологијайа на универзалнайа магија.

Покрај зоометемпсихозата и зоометаморфозата, се појавуваат и јавања/навигации на животни, со што е остварена биморфната анатомија Жена-Ж ивойно, и јавањето на мажи-коњи. ${ }^{38}$ Во Осман на Гундулиќ (II,154), мајката на Мустафа лета на овен кон планинскиот вилозмеј, каде „вештерките под орев/на гозби страшни седат“, а за кои постои фама дека „од детска/млечна плот помаз варат“. Вилозмеј е дубровничко славизирање од griffone >grip. Потврдата е важна, зашто вилите ги поставува во врска со вештерките“. (Skok, 1973: 593). ${ }^{39}$ И. Ујевиќ (I. Ujević, 1896: 232) приопштува за Вргорац дека нокум вештерката „зема некоја прачка, па удара по каминот. Каминот се раствара, излегува лонец полн маст. Се намачкува. Тогаш иде црн овен. Она јавнува на него и говори: 'Ни од дрво ни по камен, туку во Пуља под орев!'“

Карло Гинзбург (Carlo Ginzburg) раскажува како фурланските бенанданйu, вооружени со стебленца коморач се бореле за плодност против машките (и женските вештерки) кои биле вооружени со стебленца сирак (што потсетува на облик на метла) (спореди Ginzburg, 1991: 155). ${ }^{40}$ Притоа бележи дека состојбата на летаргија и каталепсија претставува увод во нивната борба, при што духот на бенанданиии го напушта телото понекогаш во облик на глушец или на пеперуга, а понекогаш јавајќи на зајак, мачка или на некое друго животно. Наведеното патување на душата се споредува со евроазискиот шаманизам, со таа разлика што кај бенанданиииие не станува збор за ексйаза (транс) од ритуален тип (шаманска сеанса) која се одвива во најаве (ibid. :195). 
За Иваниќ Град е забележено верувањето дека постојат и цопрњаци кои имаат моќ како и цопрњиците; исто така јаваат на метла и одат на цопрњиште. (Да се присетиме на Мефистофеловото предизвикувачко прашање за Фауст: Дршка од метла зар не би сакал ти?; J. W. Goethe: Faust, 3835.) Ѓ. Стјепан Дежелиќ (Gj. Stjepan Deželić, 1863: 219) понатаму упатува на верувањето кое цопрњиците ги поврзува со моите, а кои со техниката на јавање делуваат како феминини инкуби: „еден ѝ се замерил на баба готвачка, па доаѓала ноќе да го цица, после го јавнала и отишла со него Бог знае колку далеку“. ${ }^{41}$ По мориниот гест на цицање следи реално (коњаничко) јавање на маж („стаи на него оглав и стана слугата коњ“). Наведената зоометаморфоза на мажот во коњ ја повикува во митската меморија волшебничката Кирка која ткаела на разбој кога Еурилох и неговите придружници влегле во нејзините одаи. Откако им понудила маѓепсана храна, почнала да ги удира со прачка (волшебно стапче), претворајќи ги во прасиња (Graves, 1961: 581). Хипоморфниот бином коњ (маж) - вештерка исто така е присутен и во имагинариумот за вилите кои за јавање ги избирале најдобрите коњи, при што вилата и вештерката во наведениот коњски галоп ја преземаат улогата на инкуб, а мажот кој се наоѓа во функција на коњ ја презема феминината улога (succubare) во односой.$^{42}$ Мијат Стојановиќ (Stojanović, 1852: 384 ) бележи дека вештерките ги претвораат мажите во коњи кои им служат ја завање, при што наведува дека вештерката има чудни канџии (камшици) со кои „што и да удрат, се претвора во коњ. Него вештерката ќе го заузда со својата узда, исплетена од везова ларва, јавнувајќи така оди на вештерски состанок, каде се забавуваат, танцуваат и се гостат“. Милан Ланг (Lang, 1914: 121) запишува дека ноќта на Ѓрѓ́овден секоја јава на својот коњ-човек „на Клек на големиот собир“. Лука Илиќ Ориовчанин (Oriov-

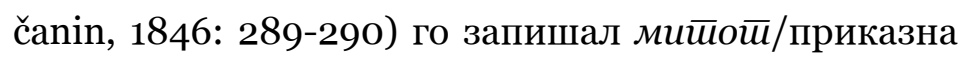
за ученикот кого неговата газдарица - вештерка го користела како коњ: ноќе, додека лежел в кревет, со узда го фукнала по глава. По хипоморфозата - „таа ме излигави, ме јавна и одлета со мене на нивниот собор“ - на неговото место во креветот ставила метла која, ако се сврти наопаку, според имитативната магија, би индуцирала негова смрт. Во наведениот запис станува збор за хипогриф, коњ (маж) крилаш, кој симболички ѝ припаѓa на уранската епифанија. Така, во Тршќе е забележено дека ц̧оиерницииие, покрај тоа што јавале на метли, избирале „посилен маж“ кого го користеле за јавање (им служел како „коњ за јавање“), при што на нив јавале од Смогва до Клек, каде што им давале да зобаай. „Ниеден маж не знаел како се вратил. Не би ни верувал дека сето тоа навистина се случило, да не пронајдел остатоци од зоб во устата“" (Tršće, 1998: 127). ${ }^{43}$

Дали е можно да се лей $а$ толку далеку во интерпретацијата на вештерското јавање на мажи, па наведената коњаничко-навигациска биморфна положба да се смета за метамофризам, облик на мазохизам во кој личноста (мажот) ја презема улогата на куче или

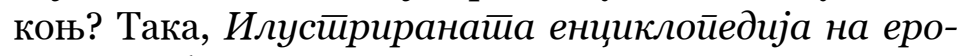
$\bar{u} и к а \bar{u} а$ (за жал, со отсуство на илустрации на метаморфизмот) упатува на тоа дека мазохистот често ја презема улогата на коњ (equus eroticus) при што неговата домина (вештата жена) јава на него, опремена со мамузи, узди и камшик, „свирепо удирајќи го и подбодувајќи го“..44

\section{Прогноза на времето за утре: вештерките и народската метеорологија}

Интересни се светлинските ипостаси (искри и светкави тела) кои биле поврзувани со вештерското 
никтоморфно тело. На пример, во Имотска краина ноќе можела да се види гламна „по воздух (...) кајшто лета, и се од неа искри прштат, тоа ти е клета вештерка, доаѓa в село“ (Kutleša, 1993: 380). ${ }^{45}$ Во имагинарната интерпратација можно е да се вбројат светлинските, сидерални парченца на вретеното на богинката (Friggjarockr) во нејзините огнени ипостаси. Исто така: на прочка и на Божик, ако ноќе од нечија куќа излета искра „и одлета низ селото, во неа сигурно има вештерки“ (ibid.). Во Сињска краина е забележено дека се видени вештерки на кои им сјаеле престилките: „(...) сѐ се сјаеше светло, а долу чорапите беа, чорапи онакви старински, а престилката цела се сјаеше, искри прштеа кога тие ќе летаа“ (Bošković-Stulli, 1967/68: 405). ${ }^{46}$ Или - примерот од Ивчевиќ Коса за вишкиие е кои на метлите спроти Ѓурѓовден одат на Клек: „Народот зборува дека таа ноќ во воздухот можат да се видат светли искри, а тоа се вишкиие кои одат на Клек“ (Hećimović-Seselja, 1985: 195). Милан Ланг (Lang, 1914: 121) бележи дека е можно да се видат „како мали факели во поле“. Во Буковица е забележено кажување според кое очевидец видел дива крушка „која целата била накитена со вештерки, па сета сјаела: на секое гранче имало по една свеќа, ќе да е дека овде правеле собир“ (Ardalić, 1917: 310-311). Исто така во Буковица постои верување дека, кога летаат во периодот на прочка, вештерките се прикажуваат во фугурација на модар пламен: „Кога се укажа светлина со модар пламен голема колку кокошка, како излегува среде Варивода 4 до 5 километри од нас, па лета па лета и во нашето село во некои куќи исчезна“(ibid. :310). Над земјата „пополека леткаат и се превртуваат една спроти друга“ (ibid.). Наведениот мокар ипостас ги вклучува во вештерскиот имагинариум талкачките свеќички (светлости-талкачки, талкачкиот пламен, душите на умрените, Irrlichter) кои имаат синкаст сјај „и тра- ат околу 15 секунди. Научниците ги толкуваат како мали количества самозапалив гас кој брзо гори“ (Ваjuk Pecotić, 1999: 174). Талкачкиот пламен, кој е поврзан со митот за пламенот, со огненото настанување на душата (светлинска пневматологија), влегува и во хесперскиот свет на Гетеовата Валӣургиска ноќ (Faust, 3855). ${ }^{47}$ Без оглед на светлинската ипостас, вештерките му припаѓаат на антисакрумот (да се послужиме со поимот на Рудолф Ото (Rudolf Otto), на натприродната енергија која го претставува елемен-

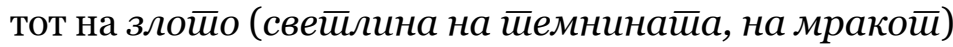
во христијанската религија и етика, на начинот како што ги предочува (по)етиката на фолклорниой имагинариум. Мирча Елијаде (Eliade, 1983: 40) упатува дека огнот има или божествено (спиритуален оган) или „демонско“ потекло „зашто тој, според некои прастари верувања, на волшебен начин настанува во половиот орган на вештерките“. Бидејќи станува збор за (вертикализмот) на издигањето, возлетувањето на душата е поврзано со светлинско-огнените морфи, но бидејќи вештерките се врзуваат со фолклорниот имагинариум за светлината на теминината, епифаниите на вештерската светлина предочуваат лунарна и стеларна светлина. Исто така, Ардалиќ (Ardalić, 1917: 309) дека на вештерките им се гледа свеќичка на главата, „вистинско пламенче“, и дека според него свештеникот може да ги препознае во црква кога „ке биде среде литургија, па кога го изнесува путирот и ја држи светињата“. ${ }^{8}$ Милчетиќ запишува дека во „Каставац (...) вештерките се жени во бела облека. Тие прават тепачки, ги сакатат луѓето, крадат и тн. (...) во Раковац (Каставско село) ги гледаат на брденцето Пелинка, кадешто летаат ваму-таму како свеќички, додека не одлетаат во долината“ (Milčetić, 1896: 233). Или да разгледаме уште една потврда за светлите ипостаси на вештерското тело: „Вештерките кои се собирале на Стајца и на Клек, се збирале и на 
Рисњак каде можеле да се видат светлечки линии (Tršće, 1998: 127). На пример, во Ивчевиќ Коса, каде ниедна жена не била осомничена дека е вештерка, се верувало дека по самрак и ноќе на несреќни места

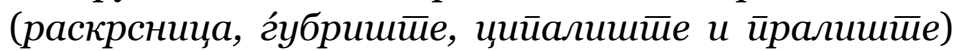
вештерките меѓусебно се тепаат со запалени гламни (факели) (Hećimović-Seselja, 1985: 130). ${ }^{49}$

Во парниците против вештерки во Хрватска, покрај останатиот демонски имагинариум, се наведувало дека жената/вештерка „создавала бура, мраз и други воздушни непогоди“ (Tkalčić, 1891: 6), па ако и „некое, посебно женско дете се осакатело: бивало набедено дека е вештерка, зашто летајќи по воздух ногата си ja скршило“ (ibid.: 9). Се верувало дека вештерките можат да кренай бура, да предизвикаат суша, поплави, град. Јохан Вајкхард Валвасор (Johann Weickhard Valvasor) во делото Славайа на војводина Крањска (1689) бележи како во 1686 година во околината на Загреб биле запалени многу вештерки и худоби (ѓаволови службенички) кои без духовен или световен суд селаните во ӣсихичка ейидемија (спореди Kazimirović, 1986: 66) ги спалувале, присилувајќи ги да ја признаат вината за неродната 1685 година. ${ }^{50}$ На пример, во Киево (Jurić-Arambašić, 2000: 401) ненадејната појава на виор, вртежен ветер, се толкувала како дејствување на вештерките кои вијай оро (архетип на врзино коло) или со верувањето според кое Ирудица го танцува своето

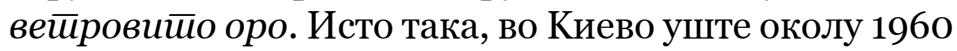
година имало „сериозни обвиненија, кавги и тепачки зашто некого го сметале за 'вештирка'“. Така, на некои места, за да се сопре градот, со пушки се пукало

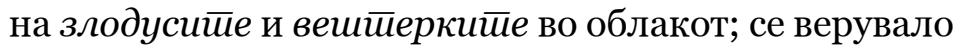
дека погодените вештерки се стрмоглавуваат од облакот на земја. И. Ујевиќ (Ujević, 1986: 232) забележал за Вргорац дека вештерките пред „крупа (град) летаат ваму-таму, а крупата со ними (sic!)“. За време на круйайа луѓето пукаат во нив зашто веруваат дека ќ ги убијат вештерките; „да ги нема нив, не би имало ни крупа“". ${ }^{1}$

ВоЗаострог се верувало дека виштерките и виштерите „ги обиваат лозјата и ги посивуваат со град“ (Banović, 1918: 192), при што остваруваат орнитометаморфоза во гаврани, „што во варја почнале бој, зашто едните сакале селото да си го бранат, други да го уништат“. Исто така, наведениот судир меѓу вештерките, на пример, го спомнува и Ф. Иванишевиќ при што наведува дека вештерките се збираат во Слатинан под Сплит, а близу Трогир под еден орев каде што играат оро и се договараат на кое место ќе направат штета да ги „удри град“. „Таму повеќепати ќе се истепаат, па кои ќе победат, не го даваат своето место, туку ќе навалат на она што е освоено“ (Ivanišević 1905: 231)..$^{2}$

Јосип Котарски (Josip Kotarski, 1918: 49) за Лобор бележи дека цоперниците летаат во магла „во воздух“, и притоа наведува дека во овој протоерејски динамизам можат „секако да сепреобразат“.Наведува дека седница држат на Велики петок ноќе (ibid. :50), при што имаат маса на смрека која е без врв. Се наведува дека можат со една нога да стојат на еден брег, со другата на другиот „и меѓу тие брегови мора да удри град, ако тие сакаат“ (ibid.), што значи дека градот (значи, урината) го праќаат од подрачјето на вагиналниот триаголник (својата еротичка метла/ четка).

Приказната за вештерките можеме да ја завршиме со дијагноза дека и покрај големите свештеници на христијанството, паганската религија успеала да преживее, на пример, во облик на Wicce која ја 
изградила концептуалната рамка на мистичкиот пантеизам со кој се карактеризира почитувањето и хармонијата со Природата (Baigent - Leigh, 2000: 63). Црквайа настојувала да го задржи своето право врз чудойо, а секое друго чудо го прогласувала за ерес. Правоверно е само христијанското чудо; меѓутоа, може ли Христовото одење по вода (Maӣej 14, 22-26) да се вброи во христијански чуда (miraculum) или пак во практиката на сидхи-моќите?53

\section{И на крајот на есеистичкиот прилог на сенки - прогноза за времето утре:}

Ким Стенли Робинсон (Kim Stanley Robinson) во научно-фантастичниот роман Синиой Марс (1997), во завршниот роман на трилогијата-сага за терафромирањето и колонизацијата на Марс во 21 и 22 век, бележи дека во темелот на човечката култура е невротската реакција на човечките најрани психички рани. „Пред раѓањето и во детството луѓето живеат во нарцисно океанско блаженство, во кое поединецот е вселена. Кон крајот на периодот на доење, сфаќаме дека смепосебни поединци, различни од својата мајка и од сите други. Никогаш целосно не се опоравуваме од тој удар“. Притоа, постојат неколку невроииччни

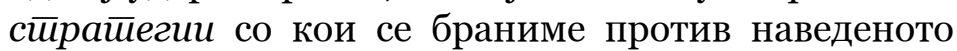
йознание-удар. „Прво, регресивното повторно стопување со мајката. Потоа, негирањето на мајката и преносот на его-идеалот на таткото: таа стратегија често трае засекогаш и луѓето во таа култура го обожаваатсвојоткралибогтатко.Илипакего-идеалот може да се помести на апстрактните идеи или на братството на сите луѓе“. Називите на тие комплекси се-дионизиски, иерсејски, айолониски, херкуловски. Сите се невротични зашто водат во мизогинија, освен дионизискиот комплекс. „Аполонискиот и херкуловскиот комплекс добро ги опишуваат овоземните индустриските општества, а персејските постарите култури, секако, со значајни остатоци сѐ до денешни денови. Сите три се патријархални. Сите три го порекнуваат мајчинството, кое во патријархатот е поврзано со телото и со природата. Женската страна била нагон, тело и природа, додека машката била разум, ум и право. А правото владеело“. На Марс можеби его-идеалот ќе се по-врати кон мајчинското, дионизиското, или кон некој вид постедипална повторна интеграција со природата, која сѐ уште ја создаваме. ${ }^{54}$

Превод од хрватски јазик: Татјана Митревска и Душица Димитровска Гајдоска

Белешки

1. Натко Нодило (Natko Nodilo, 1981: 139), според интерпретациите на Анжел де Губернатис (Angela de Gubernatisa), упатува на симболизацијата на мачор како зооморфна ноќ: „со злокобно острите свои ноќно раширени зеници, е како некоја зооморфоза на ноќта“".

На пример, во Самобор е забележено верувањето дека цопрниците „имаат околу себе помош од лилјаци и маџарони (саламандери) (Lang, 1914: 121).

2. Женски демони, вештерките се црни (спореди Živančević, 1963: 45), при што во Макарска, лошата жена ја нарекувале „црностриг“.

3. Интересно е што Canon Episcopi (околу 90о. година) не го бележи народското верување во ноќниие 
мажјаци (спореди Lucka, 1951: 176), што значи дека ноктуралните летови им се припишани само на лесните/леснокрили жени, ноќните женскички (ibid.) во фигурацијата на женската телесна проsирност.

4. Во Ватикан во 1999 година е објавен нов обредник За

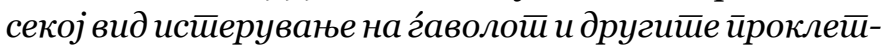
сиива, којшто Папата го потпишал на 1.10.1998 година (според Bešker, 2001: 95). Момчињайа на Сойонайа (од Болоња) се обвинети за „полово злоставување на мали деца и за некорфилија“. (ibid.).

5. Спореди го XII поглавје „Вештерките против сатанистите“ (Gwydion, 1994).

6. Прогонетата 'вештерка' бара правда“. Večernji list 7. 4. 2001., 10.

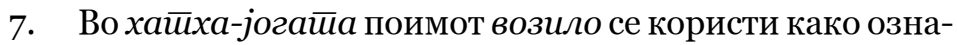
ка за физичкото тело (Lobsang Rampa, 2000: 183).

8. Предивото од вретената се премотувало во свитоци преку рашка (кој има облик на буквата Т).

Како и свртената метла, и рашката се користела како апотропеј против вештерки: „Ако мораш да бегаш од цоперница и не можеш, тогаш избегај во првата куќа, со рашка потпри ја вратата и со зелено предиво замотај ја бравата - таа не смее внатре!“ (Franković, 1990: 57)

Томо Маретиќ (Tomo Maretić, 1882: 150) според Rječnik на Караџиќ (збор: Grabilo) упатува дека вратилото „(brustbaum), на кое се намотува платното, или (...) гарнбаум, на кој се витка предивото“, на девојките им служело за гатање: „ќе застанат на него и велат: Оваа година на вратило (застанав), а догодина (дај боже) на грабило (т.е. да ме грабаат момци)“.

Во световите на уснокнижевните приказни познати се и примери на јавање на бочва; во еден пример вештерките ја намачкале бочвата, ја јавнале и одле- тале со неа од Храшч (околината на Карловац) во Сењ и назад (спореди Vrkić, 1995: 97).

9. Унгарските вештерки биле поврзувани со куќните и земјоделските алатки - со метла, вретено, срп или рало (спореди Henningsen, 1991/1992: 301).

На Блискиот Исток вештерките јавале на палмини гранки (Murray, 1970: 89).

10. Гоиниот вешӣерки фрагмент го илустрира (симболичкиот запис) во Chevalier - Gheerbrantovu Rječniku simbola - записот: Vještac (vještica).

Спореди Elke Linda Buchholz: Francisco de Goya: Life and Work. Könemann, Cambridge, 1999, 82 (A fine teacher!, 1797-1798).

11. „Lov na vještice: Napokon pravda za vještice iz Salema“. Globus, 8. 6. 2001, 84.

Денес хистеријата на четирите девојчиња се толкува со последиците на „лошиот трип“ зашто веројатно јаделе р'ж контаминирана со ергот од кој се добива лСД“ (ibid.).

12. На пример, во долината на Гацка е забележено верувањето дека дренот штити од град: „Дренката се пали и се става под првиот рожник во куќата, па градот престанува“ (rkp. IEF 285: 44).

13. Игор Мрдуљаш (Igor Mrduljaš, 1980: 166) за именките (во народните) стихови „Јас имам вретено/ти имаш фурка“ вели дека означуваат „пенис и вагина“.

14. Н. Нодило (N. Nodilo, 1981: 285) упатува дека во март „во пределите на Штаерска, на западната меѓа на нашиот народ“, уште во негово време се славела победат на летото над зимата. Младите селани во првите денови на март „ке земат српови и мотики, ќе застанат во оро, па одат на противничкото оро на другите момци, кои на себе имаат зимска облека, а во рацете држат 
гребла“. Судирот помеѓу пролетното и зимското оро завршува со победа на пролетното. Се упатува дека наведената борба е позната и во северна Германија и Англија, а особено во скандинавските краеви „каде, заради позимското поднебје, се одвива на првиот ден на мај“.

15. Спореди John Perkins: Putovanje duše (psihonavigacija): tehnike za putovanje kroz vrijeme i prostor. Novo doba: Zagreb (s.a.).

16. Аргиваните ја почитувале месечината во обличје на крава (Ија) со оглед на тоа дека рогестата млада месечина се смета за извориште на сите води. Нејзините три бои - бела за младата месечина, црвена за полната, жетвена месечина, црна за месечината која опаѓa - претставувале три старосни ери на Богинката Месечина - како девица, нимфа и старица (Graves, 1969: 161).

17. Standard Dictionary of Folklore, Mythology, and Legend. Tom I. Funk \& Wagnalls. Editor Maria Leach. New York: Funk \& Wagnalls, 1949. (Broom Goddess, 165).

18. Се разбира, Гвидион (Gwydion, 1994: 58) есента ја поврзува со симболизацијата на Yggdrasila и упатува на саксонскиот збор за вештерка - Heagteesa (гранична јавачка/ hedge ride), напоменувајќи дека поимот hedge означува граница помеѓу овој и таинствениот свет на оностраното.

Покрај Берта (Berthe) авторката ја спомнува и Хелда, Дијана и Херодија; вештерките како следбенички на „темната богинка, госпоѓата Хелда, Дијана, односно Херодија“ (ibid.)

19. 190 метли како апотропеја против мориното дејствување, спореди Marjanić, 1999. Еден дел од наведениот текст го пренесувам и во есеисииччкиой прилог на сенки за вештерската астрална метла.
Во Евангелиеӣо ӣо ирреслица (Pariz, 1855.), кое ги собира разговорите што ги водат старите за време на бдеењето, се упатува дека лошите соништа не се предизвикани од психичкиот живот, туку дека ги внесува „Кокемар или Кокемер (на југ уште и Шош-Веј)“ (Delumeau, 1987I: 125), чии никтоморфни светови се поврзани со нашайа мора.

За допирите на митските идентификации на штригата (која се претвора „во дух, мува, глувче, влакно“) и на морите, спореди, на пример, Mikac, 1934: 196-197.

20. За врските помеѓу мандрагората и зборовите мантранција, мантрање, да се мантра, спореди Medić, 1928: 268.

21. За психонавигациските вештерски формули, спореди Đorđević, 1953: 33-34.

22. Во Заоструг вештерско село кое ӣуши луле е видено под орев: „Кога тој во Пуља меѓу вешци, а тие ти наседнале во круг под едно старо ораиште, па запалиле луле“ (Banović 1918: 191). Наведеното вештерско пушачко село го здогледало едно момче отктако и самото пробало од вештерската маст (на својата стрина) и остварило пракса на навигација, но неправилна левитација со оглед дека погрешно („И по дрво и по камен и во Пуља под орас!“) ја изговорил вештерската формула. Наведеното пушење луле во вештерското село во имагинарните светови на интерпретацијата можеме да го поврземе со упатството како „далматинските селани на (...) тутунот му додавале исушен и изронет лист мандрагора, за да ја засилат аромата на тутунот“ (спореди Hruškovec, 1998: 29). Во Пригорје е забележено дека вештерките не ги напаѓаат мажите кои имаат йаверки (лулиња): „Кој пуши, од него се плашат цепрњиците“ (Rožić, 1908: 98).

23. За култот на стебла и култот на вили, спореди С̌iča, 1995: 102-104. 
Во Конавли е забележено предание за шупливата маслинка во која е собирале вештерки (Bogdan-Bijelić, 1907: 308).

В. Фортуниќ (V. Fortunić, rkp. IEF 192: 12) упатува на печурки кои „народот ги нарекува вештерска блуаница“. Се зборува дека во таа јама се собираат вештерки, затоа таму има такви печурки.“

24. Станува збор за записот на Петр Берке од делото „Kinch oszebujni szlavnoga orszaga horvatzkoga, to jezt chudnovita pripetchenya y oszebujne milosche chudnovitoga kipa Marie Biztrichke (Vu Zagrebu 1764)“ (спореди Boranić, 1912: 365).

25. Зоран Чича (Čiča, 1995: 93) кога го тематизира потеклото и начинот на стекнување на моќта на локалниот посветеник од вили, упатува како во наведените

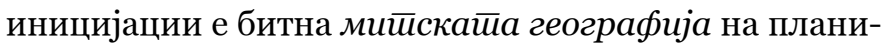
ни и стебла.

26. Во современото вештерство состојбата на голотија е означено co skyclad; ритуалната голотија остварува

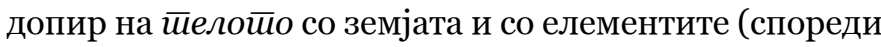
http://www.underafullmoon.com/page1004.html).

27. Велебиље (луда трева, волчја цреша, норица, Atropa belladonna L.) е едно од нашите најотровни растенија. „Кога човек ќе се измами и ќе касне од нејзините слаткасти бобинки, тогаш според приказната на очевидци формално лудува, оди како збудален и зборува сешто. Кога ќе проголта повеќе такви зрнца, тогаш тие предизвикуваат некој вид беснило со привиденија, вкочанетост, бесознание и некоординирани движења на телото. Тогаш народот вели: 'нагазил на врзино оро,' ‘нагло полудел'“. (Kazimirović, 1986: 174).

Д. Хил (D. Hill, 1998: 33) упатува на четири растенија - (смртоносно) велебиље, буника, јадиќ и кукута - кои се користеле во подготовка на маст за вештерскиот лет, при што бележи дека „состојките добиени од нив лесно (...) можеле да предизвикаат халуцинации - да речеме, летање“.

28. На пример, и на тибетанските лами им е припишувана состојба на невидливост која бара сопирање на мозочната активност (Lobsang Rampa, 2000: 180). T. Lobsang Rampa упатува дека левитацијата не е добар начин на патување зашто бара огромен напор, па наведува како упатениот човек прибегнува кон астрално патување кое не претставува никаква йешкойија (ibid.).

29. Забележено е дека вештерката со маст се намачкала (i) йо глава, после што ја изговара психонавигациската формула „Ни од дрво, ни по камен, под Велебит под орас“. (спореди rkp. IEF 102: 75).

30. Д. Антонијевиќ (D. Antonijević) ја следи дистинкцијата помеѓу ексӣаза и йранс на Ж. Руже (G. Rougeta).

31. За морината психонавигација, спореди Marjanić, 1999.

32. Вештерката која остварила зоометемпсихоза во кокошка била фатена од жената-кума; „и на огниште ја однесе и таму ја тепаше и ја запрета во оној загон“.

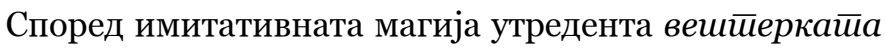
била „изгорена по лицето и по главата, и косата изгорена“ (rkp. IEF 172 I: 129-130).

33. За фолклорниот имагинариум според кој една мажена мора станува вештерка, спореди Marjanić, 1999.

Записот од Буј наведува дека мората ја именуваат уште и мора-гата или штрига-гата (итал. gatta - мачка), при што се упатува дека може да се претвори во различни животни - болва, мува, овца, коза, „ретко во кокошка, а најчесто во црна мачка. Оттука и името“ (rkp. IEF 97: 18). 
34. Како прва сукуба (succuba) од хебрејското апокрифно предание ја бележат Лилит, опишана како жена со распиштолена половост, што упатува на етиката и поетичноста на еротизмот на богинката на плодот и родот. Хебрејската народна етимологија името Лилит го изведува од именката лајла, лајил, што значи ноќ, а е поврзана со никтоморфниот имагинариум за античката вештерка која со орнитометаморфоза била определена во ноќна птица, ут (стрига - утка, утка дремливка, вревлива утка, што е задржано како едно од многубројните именувања и за нашайа вештерка) (спореди Bayer 1982: 38).

35. И додека за Словените постморталната душа е птица, за Хелените душата е пеперутка (грчки psyché - душа, пеперутка) (Nodilo, 1981: 509).

36. J. Котарски (J. Kotarski, 1918: 50) бележи дека вештерката се појавува во облик на крастава жаба, која (превентивно) треба да се прободе со колец, а „која не ја дупнуваат, туку само нејзиниот скутник“. Станува збор за хомеопатски исчекувања: прободената крастава жаба (метаморфозата на вештерката) со имитативна магија го означува дупнатиот скутник на женайа-вештерка која ќе овозможи миг на препознавање на сосейкайа-вештерка.

Спореди, на пример, вешиеерки-змии (rkp. IEF 82: 5).

37. По задачата што ја извршиле зоометаморфозираните, вештерките се враќаат на првобитното место (йод орев Боже Бакуле кој лончето со маст, откако одлетале, им го преместил йод слива): „Кога се вратија се припија до земјата, не можат да се мрднат, како залепени. Смилуј се Боже, донеси'м го лончето. Тие се намачкаа, трипати низ јаже наопаку се протнаа и станаа луѓе“ (Kutleša 1993: 385).
38. Претставите за вештерскиот ноктурален лет и териоморфните престорувања произлегуваат од народното верување (спореди Рócs, 1999: 94).

39. Skok, Petar. 1973. Etimologïski rječnik hrvatskoga ili srpskoga jezika. Knjiga treća. Zagreb: JAZU.

40. На пример, во околината на Ровињ е забележено дека крсниците и штригите „ноќе се тепаат и тоа во кватра. Штригите ги удираат крсниците со вили, крсниците вилите со метли“. (rkp. IEF 88: 37).

41. Ж. Брил (J. Bril, 1993: 145-146), кога упатува на тоналното сродство, кое е лишено од филолошка потврда, помеѓу германскиот лексем Mähre (кобила) и, на пример, нашата мори, забележува дека споменатиот германски лексем во Германија уште во 9 век служел за обележување блудници.

42. За вилинското јавање на коњи (и мажи) пишував во текстот „Životinjsko u vilinskom“ (Treća. Časopis Centra za ženske studije, br. 2/ vol. 2, 2000., 43-56).

43. Во Пригорje (Rožić, 1908:98) исто така е забележено верувањето според кое вештерката става војки/узди на мажот кој се хипоморфозира во процесот на припитомување. Во споменатиот пример станува збор за праксата на јавање која ја применува жената врз својот сойруг/коњ: „(...) на њего сека вечер јаа на Клек; уздите ќе му и стаи, и тој ќе стане коњ“ (ibid.).

44. Ilustrirana enciklopedija erotike. Zagreb: Stvarnost, 1973., 247.

45. С. Милиновиќ (S. Milinović, 1859: 217) упатува дека вештерката може да се види кога лета, „зашто се укажува како светлечка гламна“. Во Заострог (Banović, 1918: 194) се верувало во фигурацијата на вештерката како лейечки зайци. 
46. Можеби мотивот на светлински скутник во една од имагинарните интрпретации може да се постави во допир со ӣредйичњакой, као што се нарекувал белиот платнен скутник на готвачките во сватовското славје во селите на жупанијата Црквен, меѓ Бјеловар и Крижевац (Ivkanec, 1999: 143).

47. Човечката душа која се отелотворува со дишење „има огнена нарав“; фигурира како „искра што одлетува од огнот небесен“ (Nodilo, 1981: 536). „За пламеното настанување на душата не се знае догмата христијанска“ (ibid. :537).

48. На подрачјето на Зрмања „попот кога ја носи светата тајна, тогаш ги гледа сите вештерки, го гледа секое пламенче на главата, само не смее да издаде, зашто би го убиле“ (rkp. IEF 273: 44).

49. Интересно е верувањето во наведениот крај според кое спроти Ѓурѓовден во кругот на јажето во средина ќе стоел гол маж, кој би ги преплашил вештерките (спореди Hećimović-Seselja, 1985: 133, 195), што е парадоксално во однос на записите од некои краеви кои упатуваат на вештерската ритуална голотија и голотијата во левитацијата на астралните возила.

50. Janez Vajkard Valvasor, Slava vojvodine Kranjske. Izbrana poglavja, Ljubljana: Mladinska knjiga/Svet knjige, 1984, 280.

51. Раскажувачот упатува дека неговата сосетка „штом ќе види голем облак, (...) јавнува на метла, ќе се наведне, па вака гледа низ нозете кон облакот“, и потоа со гранчиња од леска „кога грми (...) го одбива градот, крсти кон облакот и нешто чита“ (rkp. IEF 172: 135). Станува збор за посебно (ритуално) подготвени (на Божик) лескови гранчиња (спореди ibid.).
52. Слично мислење забележал и А. И. Цариќ (А. I. Carić, 1897: 712) за Брач. Штриги, мори, виштици (вештерки), вишчуни и штругани се состануваат за време на бурата „во воздух на состанок, па ќе се испоразделат на чети: штригите за себе, а исто така за себе и морите, виштиците, вишчуните и штригуните, а секоја чета пак во помали чети, всушност сите од една општина или од едно исто место заедно“; и притоа се борат против Рудица (Ирудица) која со град го уништува приносот.

53. „Најголемиот дел од населението не ја сфаќал разликата помеѓу амајлијата, која свештенството строго ја забранувало, и светите реликвии. Зашто се сметало за грев да се употребуваат треви, но е препорачано да sвонат sвона, за да се изгони бурата“ (Gurevič, 1987: 197).

54. Kim Stanley Robinson, Plavi Mars. preveo Goran Vujasinović. (Zagreb: Izvori, 2001), 48-49.

\section{Библиографија}

Кратенки:

rkp. IEF - ракописна збирка на Институтот за етнологија и фолклористика во Загреб

ZNŽO - Zbornik za narodni život i običaje Južnih Slavena, $\mathrm{HAZU}$

Alpert, Richard. 1994. Seksualna tantra. Вo Tantra: zbornik tekstova/ Bhagwan Shree Rajneesh (et al.). Уредено од Damir Darmi (et al.). Zagreb: Nova arka.

Antonijević, Dragoslav. 1990. Ritualni trans. Beograd: SANU. Ardalić, Vladimir. 1917. Vile i vještice. (Bukovica u Dalmaciji). ZNŽO 22: 302-311. 
Baigent, Michael, Richard Leigh. 2000 (1997). Eliksir $i k a-$ men: naslijeđe magije i alkemije. Zagreb: Stari grad.

Bajuk Pecotić, Lidija. 1999. Kneja: 12 bajkovitih priča. Zagreb: Mozaik knjiga.

Banović, Stjepan. 1918. Vjerovanja (Zaostrog u Dalmaciji). ZNŽO 23: 190-194.

Bayer, Vladimir. 1982. Ugovor s đavlom. Procesi protiv čarobnjaka u Evropi a napose u Hrvatskoj. Zagreb: Informator.

Bešker, Inoslav. 2001. Kratka enciklopedija satanizma. Globus, 13 март: 94-99.

Bogdan-Bijelić, Pavlina pl. 1907. Vještice (Konavle u Dalmaciji). ZNŽO 13/2: 306-308.

Boranić, D. 1912. Manji prinosi. Vragovi i vještice. ZNŽO 17/2: 365-372.

Bošković-Stulli, Maja. 1959. Istarske narodne priče. Zagreb: Institut za narodnu umjetnost.

Bošković-Stulli, Maja. 1991. Pjesme, priče, fantastika. Zagreb: Nakladni zavod Matice hrvatske - Zavod za istraživanje folklora.

Bošković-Stulli, Maja. 1967-1968. Narodne pripovijetke i predaje Sinjske krajine. Narodna umjetnost 5-6: 303-432.

Bril, Jacques. 1993 (1984). Lilit ili mračna majka. Sremski Karlovci - Novi Sad: Izdavačka knjižarnica Zorana Stojanovića.

Budimir, Milan. 1966. Vampirizam u evropskoj književnosti. Anali Filološkog fakulteta. Knjiga VI:269-273. Beograd: Beogradski univerzitet.

Bujanović, J. 1896. Vjera u osobita bića. Praputnik. ZNŽO 1: 234.

Carić, Antun Ilija. 1897. Narodno vjerovanje u Dalmaciji. Štrige, ili štringe na ostrvima Braču i Hvaru. Glasnik Zemaljskog muzeja u Bosni i Hercegovini IX: 710-713.

Castellan, Yvonne. 1986 (1974). Parapsihologija. Beograd: Novo delo.

Chevalier, Jean - Alain Gheerbrant. 1987. Rječnik simbola. Mitovi, sni, običaji, geste, oblici, likovi, boje, brojevi. Zagreb: Nakladni zavod Matice hrvatske.
Cooper, Jean Campbell. 1986 (1978). Ilustrovana enciklopedija tradicionalnih simbola. Beograd: Prosveta-Nolit.

Čajkanović, Veselin. 1985. Rečnik srpskih narodnih verovanja o biljkama. Rukopis priredio i dopunio Vojislav Đurić. Beograd: SKZ-SANU.

Čiča, Zoran. 1995. Pučka kultura i povijesni proces. Neki elementi hrvatske pučke kulture u kontekstu progona vještica u ranoj modernoj Europi (magistarski rad). [rkp. IEF 1519]. Zagreb.

Däniken, Erich von. 2000. Antički letači. Tragom bogova 2. Zagreb: Zagrebačka naklada.

Delumeau, Jean. 1987 (1978). Strah na Zapadu: (od XIV do XVIII) veka: opsednuti grad. I-II. Novi Sad: Književna zajednica Novog Sada, Dnevnik.

Deželić, Gj. Stjepan. 1863. Odgovor na pitanja, stavljena po historičkom družtvu. Od Gjurgja Stjepana Deželića. Zagreb: Arkiv za povjestnicu jugoslavensku. Knjiga VII: 199-232.

Durand, Gilbert. 1991 (1984). Antropološke strukture imaginarnog. Uvod u opću arhetipologïu. Zagreb: August Cesarec.

Duić, A. 1896. Gorski kotar u Hrvatskoj. ZNŽO 1: 285-287.

Đorđević, Tihomir R. 1953. Veštica i vila u našem narodnom verovanju i predanju. Vampir i druga bića u našem narodnom verovanju i predanju. Srpski etnografski zborn$i k$ LXVI. Beograd: SANU.

Eliade, Mircea. 1983 (1977). Kovači i alkemičari. Zagreb: GZH.

Eliade, Mircea. 1985 (1968). Šamanizam i arhajske tehnike ekstaze. Novi Sad: Matica srpska.

Ensler, Eve. 2000 (1998). Vaginini monolozi. Zagreb: V. B. Z.

Faust, Viktoria. 2000. Vještice: knjiga sjena. Zagreb: Zagrebačka naklada.

Franković, Đuro. 1990. Mitska bića u podravskih Hrvata: narodne predaje. (Etnografija Južnih Slavena u Mađarskoj 9). Budimpešta: Tankönyvkiadó.

Ginzburg, Carlo. 1991 (1989). Ecstasies: Deciphering the Witches' Sabbath. London: Penguin Books. 
Graves, Robert. 1969 (1955). Grčki mitovi. Beograd: Nolit.

Graves, Robert. 1977 (1948). The White Goddess: A historical grammar of poetic myth. London: Faber and Faber Limited.

Grčević, Jure. 2000. Kompolje: narodni život i običaji. Otočac: Katedra Čakavskog sabora pokrajine Gacke.

Gurevič, Aron Jakovljevič. 1987 (1981). Problemi narodne kulture u srednjem veku. Beograd: Grafos.

Gwydion. 1994. Vika - drevna religija veštica. Beograd: Esotheria.

Hećimović-Seselja, Mara. 1985. Tradicijski život $i$ kultura ličkoga sela Ivčević Kosa. Zagreb: Mladen Seselja; Gospić: Muzej Like.

Henningsen, Gustav. 1991/92. The white sabbath and the other archaic patterns of witchcraft. Acta Ethnographica Hungarica (Special Issue: Witch Beliefs and Witchhunting in Central and Eastern Europe, Conference in Budapest, Sept. 6-9, 1988) Volume 37, Numbers 1-4: 293-304.

Hill, Douglas. 1998 (1997). Vještice i čarobnjaci. Zagreb: Knjiga trgovina.

Hozzel, Malte. 1991. Levitacija: od mistike do znanosti. Beograd: Hodoba Kata.

Hruškovec, Tomislav. 1998. Đavlu zapisane: o vješticama u Zagrebu i Hrvatskoj. Zagreb: Imprime.

Hughes, Pennethorne. 1975 (1952). Witchcraft. London: Penguin Books.

Ilić Oriovčanin, Luka. 1846. Narodni slavonski običaji. Zagreb: Franjo Suppan.

Ivanišević, Frano. 1905. Poljica. Narodni život i običaji. Kakovu snagu imadu neki ljudi. ZNŽO 10/2:227-254.

Ivkanec, Ivanka. 1999. Erotika i tradicijska narodna nošnja. Во Tijelo u tranziciji. Уредено од Djurdja Bartlett. Zagreb: Tekstilno-tehnološki fakultet, zavod za dizajn tekstila i odjeće.

Jardas, Ivo. 1957. Kastavština. ZNŽO 39: 102-115.

Jurić-Arambašić, Ante. 2000. Kijevo: narodni život i tradicijska kultura. ZNŽO 54.
Kadčić Peka, B. Petar. 1859. Odgovori na njekoja pitanja družtva za jugoslavensku povjestnicu i starine. Iz kotara Makarskoga. Zagreb: Arkiv za povjestnicu jugoslavensku. Knjiga V [Vještica: str. 332-333].

Kazimirović, Radovan N. 1986 (1940). Tajanstvene pojave u našem narodu. Kremansko proročanstvo. Čaranje, gatanje, vračanje i proricanje u našem narodu. Prilog ispitivanju tajanstvenih duhovnih pojava. Smederevo: Arion.

Kotarski, Josip. 1918. Lobor. ZNŽO 23: 49-50.

Kutleša, Silvestar fra. 1993. Bo Život i običaji u Imockoj krajini. Уредено од Vesna Čulinović-Konstantinović. Imotski: Matica hrvatska Ogranak Imotski.

Lang, Milan. 1914. Samobor. Kakvu snagu imadu neki ljudi. ZNŽO 19/1: 121-127 [Copernice:].

Laszowski, Emilij. 1914. Progon vještica u Turopolju. Vjesnik kr. hrvatsko-slavonsko-dalmatinskoga zemaljskog arkiva, godina XVI:196-208.

Lobsang Rampa, T. 2000.Treće oko. Zagreb: Misl.

Lovrenčević, Zvonko. 1969-1970. Mitološke predaje Bilo-gore. Narodna umjetnost 7: 71-100.

Lovrić, Ivan. 1948 (1776). Bilješke o putu po Dalmaciji opata Alberta Fortisa $i$ Život Stanislava Sočivice. Zagreb: Izdavački zavod Jugoslavenske akademije.

Lucka, Emil. 1951. Torquemada i inkvizicija u Španjolskoj. Zagreb: Novo pokoljenje.

Maretić, Tomo. 1882. Studije iz pučkog vjerovanja i pričanja u Hrvatâ i Srbâ. Rad JAZU LX: 117-220.

Marjanić, Suzana. 1999. Zaštitna sredstva protiv mòre kao žensko-niktomorfnog demona. Treća: časopis Centra za ženske studije br. 2/ vol. 1: 55-71.

Medić, Mojo. 1928. Folklorističke dopune. ZNŽO 26/2: 257275.

Mikac, Jakov. 1934. Vjerovanja (Brest u Istri). ZNŽO 39/2: 195-200.

Milčetić, I. 1896. Vjera u osobita bića. Otok Krk, i kajkavci. ZNŽO 1: 232-233. 
Milinović, Simeon. 1859. Kratko opisanje Lovreća u Dalmaciji s narodnimi običaji. Zagreb: Arkiv za povjestnicu jugoslavensku, Knjiga V.

Motz, Lotte. 1996. The King, The Champion and The Sorcerer. A Study in Germanic Myth. Wien: Fassbaender.

Mrduljaš, Igor. 1980. Kudilja i vreteno - sjenovito mjesto narodnog pjesništva. Bo Kudilja i vreteno: erotske narodne pjesme. Уредено и поговор Igor Mrduljaš. Zagreb: Znanje.

Murray, Margaret A. 1970. The God of the Witches. Oxford: Oxford University Press.

Nodilo, Natko. 1981 (1885-1890). Stara vjera Srba i Hrvata (Religija Srbâ i Hrvatâ, na glavnoj osnovi pjesama, priča i govora narodnog). Split: Logos.

Pandian. Jacob. 1991. Culture, religion, and the sacred self: a critical introduction to the anthropological study of religion. New Jersey: Prentice Hall, Englewood Cliffs.

Petek-Stupar, Martina. 1999. Prikaz knjige Erice Jong 'Vještice'. Kruh \& ruže 11: 77-83.

Petersdorff, Egon von. 2001 (1960). Demoni, vještice, spiritisti: sve o postojanju i djelovanju mračnih sila. Split: Verbum.

Pócs, Éva. 1999. Between the Living and the Dead: A Perspective on Witches and Seers in the Early Modern Age. Budapest: Central European University Press.

Radenković, Ljubinko. 1996. Narodna bajanja kod Južnih Slovena. Beograd: Prosveta.

Rountree, Kathryn. 1999. Nova vještica Zapada: feministkinje prisvajaju staru vješticu. Treća: časopis Centra za ženske studije br. 2/vol. 1: 73-83.

Rožić, Vatroslav. 1908. Prigorje. Narodni život i običaji. Kakvu snagu imadu neki ljudi. ZNŽO 13/1:97-98.

Sofrić Niševljanin, Pavle. 1912. Glavnije bilje u narodnom verovanju i pevanju kod nas Srba po Angelu de Gubernatisu. Beograd: Štamparija „Sv. Sava“.

Starhawk. 2000. Spiralni ples: preporod drevne religije Boginje. Zagreb: Liberata.
Stojanović, Mijat. 1852. „Odgovor na pitanja“. Arkiv za povjestnicu jugoslavensku. Knjiga II: 346-403.

Stojković, Marijan. 1934. Pojas. ZNŽO 29/2: 1-19.

Stojković, Marijan. 1935. Sobna prašina, smeće, metla i smetlište. ZNŽO 30/1: 17-31.

Tkalčić, Ivan. 1891. Parnice proti vješticam u Hrvatskoj. Rad JAZU 103: 3-36.

Tršće. 1998. Уредено од Branka Arh. Čabar: Finvest.

Ujević, I. 1896. Vjera u osobita bića. Vrghorac. ZNŽO 1: 232.

Valjavec, M. 1863. Odgovori na njekoja pitanja družtva za povjestnicu i starine jugoslavenske. U Varaždinu i njegovoj okolici. Arkiv za povjestnicu jugoslavensku. Knjiga VII: [O coprnicah: 253-254]. Zagreb

Vrkić, Jozo. 1995. Vražja družba: hrvatske predaje o vilama, vješticama, vrazima i drugim nadnaravnim bićima. Zagreb: Glagol.

Vukanović, T. P. 1971. Studije iz balkanskog folklora III. Vranjski glasnik 7: 165-274.

Zečević, Slobodan. 1964. Ljeljenovo kolo. Narodno stvaralaštvo - Folklor 9-10: 702-710.

Zubac-Ištuk, Ruža. 1994. Narodno blago i običaji livanjskog kraja. Vinkovci: Slavonska naklada „Privlačica“.

Živančević, Vladimir. 1963. Volos - Veles, slovensko božanstvo teriomorfnog porekla. Glasnik Etnografskog muzeja 26: 33-66.

Ракописни збирки

rkp. IEF 82 Lelja Taš. Narodne pjesme, običaji, praznovjerja i pripovijetke okolice Buja. 1952.

rkp. IEF 88 Nikola Bonifačić Rožin. Hrvatske narodne pjesme, priče i običaji iz kotara Poreč i okolice Rovinja. 1952.

rkp. IEF 97 Ive Jelenović: Folklorni materijal - Buje. 1952.

rkp. IEF 102 Maja Bošković-Stulli: Narodne pjesme, pripovijetke i običaji iz okolice Šibenika i Drniša. 1952. 
rkp. IEF 172 (I.) Maja Bošković-Stulli: Narodne pjesme, priče, običaji i drugo iz Banije I. 1954.

rkp. IEF 172 Maja Bošković-Stulli: Folklorna građa Banije (narodne pripovijetke, praznovjerja, pjesme, običaji). 1954 .

rkp. IEF 192 Fortunić, Vlaho. 1937. Iz narodne folklore o morama i vješticama te o urocima i vukodlacima.

rkp. IEF 273 Maja Bošković-Stulli. Folklorna građa sa Zrmanje. 1957.

rkp. IEF 285 Ivan Ivančan: Folklorna građa iz doline Gacke $i$ okolice Perušića. 1958.

rkp. IEF 783 Nikola Bonifačić Rožin: Folklorna građa otoka Korčule. 1966.

rkp. IEF 1127 Ante Buljan: Opis običaja rodnog kraja Sinja, Imocki, Vrljika, Livna kao i pripadajuće okoline. 1985. 